\title{
Ulbricht and the Intellectuals
}

\section{JOHN CONNELLY}

Khrushchev's secret speech of February 1956 threw the moral and political world of East Central Europe's intellectuals into turmoil. One of the most secure belief systems ever devised was suddenly revealed to be the ideological justification for crimes of a massive scale. Several generations of Communists groped for orientation, and radical change seemed inevitable. East Germany's intellectuals were no exception in their expectations and desires for change. Students of the GDR have always understood 1956 as one of formidable intellectual challenge to the Ulbricht regime, and the opening of SED and Stasi archives has strengthened this view, revealing an unrest that pervaded the ranks of students, writers, teachers, and much of the Party cadre. ${ }^{1}$

Yet this remarkable intellectual ferment did not achieve a lasting effect. Despite the presence of leading Eastern European revisionists such as Ernst Bloch, Wolfgang Harich, Jürgen Kuczynski, Robert Havemann, Arne Benary or Fritz Behrens, East German society failed to produce an abiding intellectual challenge to the Stalinist regime. The year 1956 in East Germany did not have the historical resonance for future generations of dissidents that it had for counterparts in Poland or Hungary. By the 1970s the story of that year was hardly known - even to the new generation of dissidents. ${ }^{2}$

Existing scholarship provides only partial answers for this East German anomaly. Early analysts focused explanations upon the Party apparatus. Writing in 1960, William E. Griffith identified revisionism as the 'revolt of Party intellectuals against the apparatchiki'. It had gone furthest in Poland and Hungary where the Party apparatus was small, but was easily crushed in Czechoslovakia and East Germany,

I would like to thank the American Council of Learned Societies, the Spencer Foundation, the Center for German and European Studies (Berkeley, CA) and the Slavic Center (Berkeley, CA) for assisting my research, and Fiona N. Grigg, György Péteri and Andrew Barshay for their helpful comments.

1 See esp. Armin Mitter and Stefan Wolle, Untergang auf Raten: Unbekannte Kapitel der DDR-Geschichte (Munich: Bertelsmann, 1993), and Manfred Hertwig, 'Der Umgang des Staates mit oppositionellem und widerständigem Verhalten. Die Opposition von Intellektuellen in der SED/DDR in den fünfiger Jahren (insbesondere 1953, 1956/57), ihre Unterdrückung und Ausschaltung', in Deutscher Bundestag, (ed.), Materialien der Enquete-Kommission 'Aufarbeitung von Geschichte und Folgen der SED-Diktatur in Deutschland' (Baden-Baden: Nomos, 1995), vii. 873-95. Standard accounts are Karl Wilhelm Fricke, Opposition und Widerstand in der DDR (Cologne: Verlag Wissenschaft und Politik, 1984), and Martin Jänicke, Der Dritte Weg: Die antistalinistische Opposition gegen Ulbricht seit 1953 (Cologne: Neuer Deutscher Verlag, 1964).

${ }_{2}$ Materialien der Enquete-Kommission, vii. I 40, and Die Zeit, US ed., Vol. 51, no. 47 (1996), 8. 
'where adequate numbers of apparatchiki were available'. ${ }^{3}$ More recent treatments of East German intellectuals' failure to constitute a more cohesive reform movement have stressed their unique commitment to socialism and anti-fascism, and the supposed inability both of the SED and its opponents to appeal to nationalism. ${ }^{4}$

Such explanations have only limited power. The apparatus of the Czech Communist Party did not hinder the Prague Spring after all, ${ }^{5}$ and in East Germany intellectuals never actively supported de-Stalinisation. Why was this so? The SED's success in limiting intellectual dissent in the late I950s may help provide the answers.

East German intellectuals' commitment to socialism and anti-fascism are likewise at best partial explanations. Counterparts in Poland, Czechoslovakia, and Hungary were hardly less devoted to socialism than their East German counterparts. ${ }^{6}$ And though anti-fascism was bound to have great force in the country which launched Hitler, it was by no means limited to East German intellectuals. Many leading Polish, Czech, Slovak or Hungarian intellectuals had suffered the effects of right-wing nationalism and fascism, and been rescued in 1945 by the Red Army. ${ }^{7}$ Furthermore, East German anti-fascism had a largely mythical character: from an early date the East German state began to integrate former Nazis, and by the mid-I95os almost a third of the members of the SED had been members of Nazi organisations. ${ }^{8}$

3 William E. Griffith, 'The Decline and Fall of Revisionism in Eastern Europe', in Leopold Labedz, (ed.), Revisionism. Essays on the History of Marxist Ideas (New York: Praeger 1962), 227.

4 John C. Torpey, Intellectuals, Socialism, and Dissent. The East German Opposition and its Legacy (Minneapolis MN: University of Minnesota Press, 1995), 40-1; Sigrid Meuschel, Legitimation und Parteiherrschaft in der DDR (Frankfurt: Suhrkamp, 1992), I 52-68; Christian Joppke, East Cerman Dissidents and the Revolution of 1989 (New York: New York University Press, 1995), 23-9, 183-200.

5 The Czechoslovak liberalisation of the I960s in many ways began in I956. See Vladimir V. Kusin, The Intellectual Origins of the Prague Spring: The Development of Reformist Ideas in Czechoslovakia 1956-1967 (Cambridge: Cambridge University Press, 1971), 19-27; the comments of A. Liehm in V. V. Kusin, The Czechoslovak Reform Movement 1968 (London: International Research Documents, 1973), 6778. For accounts of student demonstrations in Prague and Bratislava, see Neue Zürcher Zeitung, 16 June, 7 July 1956; The New York Times 22 May, is June 1956; Hinter dem Eisemen Vorhang, July 1956; RFE Reports, item nos 5569,5741 , 5742, 5924, 7912/56.

6 Large majorities of writers of several generations thoughout East Central Europe warmly embraced Soviet-style socialism. See Czesław Miłosz, The Captive Mind (New York: Vintage, 1981), Jacek Trznadel, Hańba domowa. rozmouy z pisarzami (Lublin: Wydawnictwo Test, I99I); Peter Hruby, Fools and Heroes. The Changing Role of Communist Intellectuals in Czechoslovakia (Oxford: Pergamon, 1980); Tamas Aczel and Tibor Meray, The Revolt of the Mind (New York: Praeger, 1959). This view contrasts with that offered by Heinrich Olschowsky, 'Das Jahr 1956 in der literarischen Szene der DDR', in Hans Henning Hahn and Heinrich Olschowsky, (eds.), Das Jahr 1956 in Ostmitteleuropa (Berlin: Akademie Verlag, 1996), I 33.

7 See, for example, Peter Kenez, Varieties of Fear: Growing Up Jewish under National Socialism and Communism (Washington, DC: American University Press, 1995); Edward Goldstücker, Prozesse: Effahrungen eines Mitteleuropäers (Munich: A. Knaus, 1989); Heda Margolius Kovaly, Under a Cruel Star: A Life in Prague 1941-1968 (Cambridge, MA: Plunkett Lake Press, 1986); Jan Kott, Still Alive (New Haven: Yale University Press, 1993); Janina Bauman, A Dream of Belonging: MY Life in Postwar Poland (London: Virago, 1986); Tomas Venclova, Aleksander Wat: Life and Art of an Iconoclast (New Haven: Yale University Press, 1996).

8 In early I954 almost one in ten SED members had belonged to the NSDAP; fully 27 per cent were members of one of its subordinate organisations. Jan Foitzik, "Die stalinistischen "Säuberungen" in den ostmitteleuropäischen kommunistischen Parteien. Ein vergleichender Überblick', Zeitschrift für Geschichtswissenschaft, Vol. 40, no. 8 (1992), 745 . 
'Nationalism' or 'national communism' likewise appear unsatisfactory upon closer examination: on the one hand the SED regime, and no doubt much of its following, perceived itself as the truly patriotic German state. For an East German intellectual of the I950s, the Ulbricht regime's agitation in the name of the German nation needed be no less credible than its agitation in the name of Marxism. On the other hand, the 'National Communist' regimes of Poland, or later Slovakia, were as successful in quelling intellectual dissent as in supporting it. Moreover, intellectuals in Poland or Hungary in 1956 considered their actions to be carried out in the name of socialism as much as in the name of their nations. ${ }^{9}$

This essay hopes to reach a more balanced understanding of East German intellectuals in the r 950 os blacing them in their context: that is by seeing them against the background of other socialist states in the region. It argues that two factors truly distinguished East Germany's intellectuals: the SED leadership's unique attention to the challenges of creating a new élite, ${ }^{10}$ and an intellectual culture marked by primary loyalty to the Party/state. Counterparts elsewhere in East Central Europe identified primarily with an historical formation called the "intelligentsia'. ${ }^{11}$ Any intelligentsia in the GDR was a creation of the SED, however, and it had been formed in both positive and negative senses. On the one hand the SED consciously chose members of the new intelligentsia, and on the other it acted to exclude the influence of 'bourgeois' or 'reactionary' elements through repression and an open border to the West.

The understanding of intellectuals used here is a broad one, including writers and artists, but also university communities and especially students. ${ }^{12}$ Students have been known throughout East Central Europe for their role in pressing for change at critical moments. Everywhere, that is, except in East Germany.

\section{Early Challenges and Early Policies}

The Soviet Military Administration in Germany and its German (SMAG) Communist helpers were determined from the immediate post-war days to influence decisively the emergence of a new intelligentsia on German soil. They were equally determined to hinder intellectual dissent. This is most visible in university policy. ${ }^{13}$ In the summer of 1945 the professorial bodies of all six universities of the Soviet

9 Aczel and Meray, Revolt; Peter Raina, Political Opposition in Poland (London: Poets and Painters Press, 1978), 39-44; Andrzej Friszke, Opozycja polityczna w PRL 1945-1980 (London: Aneks, 1994), 67.

10 Several scholars have posited the SED's comparative success in transforming élites. Meuschel, Legitimation, I 28-9; Mary Fulbrook, Anatomy of a Dictatorship: Inside the GDR 1949-1989 (Oxford: Oxford University Press, 1995), 81.

1 For the absence of such an intelligentsia in the GDR see Melvin Croan, 'East German Revisionism: The Spectre and the Reality', in Labedz, Revisionism, 240.

12 This approximates Emst Richert's conception of a three-fold division of the East German intellectual community: students, writers and social scientists. 'Sozialistische Universität'. Die Hochschulpolitik der SED (Berlin: Colloquium, 1967), 142.

13 For a discussion of controls over the production of art and literature in the early post-war period, see David Pike, The Politics of Culture in Soviet-occupied Germany 1945-1949 (Stanford, CA: Stanford University Press, 1992). 
Zone had re-convened and begun to purge themselves of former Nazis, but the new authorities proved very suspicious of these efforts. Conflicts ensued over precise numbers, with the universities insisting that certain professors had to be maintained in order to guarantee basic university functions. The Soviets responded to German obstinance with an order in early 1946 that every former Nazi be removed from teaching staffs, something the Germans - and Western powers considered fantastic. ${ }^{14}$ The rectors of Rostock, Leipzig and Berlin were replaced by more compliant colleagues; and the rector of Greifswald, the theologian Ernst Lohmeyer, was arrested the day before the scheduled university re-opening in January 1946 . He was never heard from again. ${ }^{15}$

As a result of this de-Nazification the number of university teachers active in the Soviet Zone dropped by over two-thirds. ${ }^{16}$ This was the most decisive break in professorial continuity in East Central Europe, for the purges touched every faculty. The Czech purges of 1948 were severe, but left medical and natural science faculties essentially intact. ${ }^{17}$ It was also the earliest point at which Communist authorities in East Central Europe began forming a new intelligentsia. Soviet or German Communist agencies had to approve not only the hiring of every new university teacher, but also the admittance of each new student.

Soviet and German Communists co-operated ${ }^{18}$ in student admissions policies, which were seen as the groundwork for building a new academic élite. According to guidelines of early 1948 , the goal of worker courses was the 'formation of the next generation of academics from such strata of the people (workers, peasants, victims of fascism and victims of national socialism) as have been excluded from high school for social or political reasons'. ${ }^{19}$ Early in 1946 , special faculties were set up throughout the Soviet Zone to prepare worker and peasant children for university. Previously, people from such social strata had been all but denied entrance to university. Through a process of trial and error the SED devised methods of selection and teaching that guaranteed strong contingents of students from these social strata who would succeed at university. The East German worker-

14 On the purging, see Mitchell G. Ash, 'Denazifying Scientists - and Science', in M. Judt and B. Ciesla, (eds.), Technology Transfer out of Germany after 1945, (Chur, 1995).

15 Marianne and Egon Erwin Müller, '. . stümt die Festung Wissenschaft!' Die Sowjetisierung der mitteldeutschen Universitäten seit 1945 (Berlin: Colloquium Verlag, 1953), 65; Universitätsarchiv Greifswald, personnel file Emst Lohmeyer.

16 Bundesarchiv, Abteilungen Potsdam, (BAAP), R2/1060/2I.

17 See, for example, the faculty listings in František Jordan, (ed.), Déjiny University v Bmé, (Brno: Universita J. E. Purkyně, I969), 370-84.

18 Soviet officers strongly encouraged the German administration to increase rapidly the numbers of workers at the universities. Examples in Stiftung Archiv der Parteien und Massenorganisationen im Bundesarchiv (SAPMO-BA); Zentrales Parteiarchiv (ZPA), Berlin, IV2/9.04/697 (unnumbered); Hans-Hendrik Kasper, 'Der Kampf der SED um die Heranbildung einer Intelligenz aus der Arbeiterklasse und der werktätigen Bauemschaft über die Vorstudienanstalten an den Universitäten und Hochschulen der sowjetischen Besatzungszone Deutschlands 1945/46-1949', PhD Thesis (Freiberg i. S., 1979), 172; BAAP, R2/4008/56.

19 BAAP, R2/900/13-I4. 
peasant faculties became the most serious in the region (see Table I) and, indeed, outdid even the Soviet variant in consistency of application. ${ }^{20}$

Table I. Worker-peasant courses

\begin{tabular}{lll}
\hline \hline Country & Years of operation & $\begin{array}{l}\text { Percentage of university admissions } \\
\text { from worker-peasant courses }\end{array}$ \\
\hline GDR & $1946-66$ & 20 \\
Czech Lands & $1949-54$ & $10-13$ \\
Poland & $1945-55$ & $8-9$ \\
\hline \hline
\end{tabular}

Soviet and East German Communists complemented these affirmative action policies with a careful ideological policing of university terrains. At first they may have harboured some belief that such policing would not be necessary given that student admissions policies were meant to screen students tainted by fascist ideology. In 1946 the SMAG even permitted student councils to emerge throughout the Zone. Yet students did not behave as expected: in two freely contested elections in 1947 they elected liberals and Christian Democrats. The SMAG responded with changes in election procedures, and growing terror: over 400 students and professors were arrested in East Germany between 1945 and mid-1953. ${ }^{22}$ Students of the immediate post-war years proved to be the group in East German society least willing to accept the increasingly authoritarian regime, and thereby reinforced the determination of the SMAG and SED to direct the formation of a new intelligentsia. ${ }^{23}$

Such determination extended to the top tiers of the leadership, and in this the SED was extraordinary. There are no records of Klement Gottwald, Rudolf Slánský, Władysław Gomułka or Bolesław Bierut intervening in favour of worker studies at any point. ${ }^{24}$ Walter Ulbricht, on the other hand, constantly involved himself in the formation of the new élite: from Marxist-Leninist schooling to special legal training, stipends, sport instruction, recruiting of women and, of course, the worker-peasant faculties. In I950, he personally adjusted the numbers of

20 The Soviet model for such courses, the rabfak, was used intensively only in the early postrevolutionary period and during the Great Break (1928-32). It was scaled down and then abandoned altogether in the 1930s. See Sheila Fitzpatrick, Education and Social Mobility in the Soviet Union 1921-1934 (London: Cambridge University Press, 1979).

21 The East German total represents an average figure from 1952/6. The Czech and Polish numbers are from peak periods in the early i9sos. Státni ústredni archiv, Prague (SÚU) ÚPV 248 I I $2 /$ 3.81.43/54; Archiwum Akt Nowych, Warsaw (AAN) MSW 17/91-2; KC PZPR 237/XVI/I 20/43; I 21/103-5; Statistisches Jahrbuch der Deutschen Demokratischen Republik 1960/61 (Berlin: VEB Deutscher Zentralverlag, 1961), 132-3.

22 Müller, ' . . stürmt die Festung Wissenschaft', 364-79. By 1956 that number had grown to 579. Report of Horst Böttcher, 28 Aug. 1956, SAPMO-BA IV2/9.04/667 (unnumbered).

23 John Connelly, 'East German Higher Education Policies and Student Resistance, 1945-1948', Central European History, Vol. 28, no. 3 (1995).

24 In Prague, see the Klement Gottwald papers, esp. SÚA-AÚV KSČ, f. roo/24 a.j. 956,975,978; f. 19/7 a.j. I-346; in Warsaw, see the Party collections AAN KC PPR 295/XVII, KC PZPR 237/XVI, and the state collections of Ministerstwo Oswiaty and Ministerstwo Szkolnictwa Wyższego. 
worker-peasant students to be admitted, demanding that they be increased threefold. ${ }^{25}$ At least in part due to this decisive central will, the SED apparatus was likewise keenly interested in élite-building, and maintained the constant pressure on trade union, youth (FDJ) or basic party cells necessary to direct the ideological and technical education of young cadres.

The results are readily apparent in a comparative glance at student recruitment and stipends (Tables 2 and 3). SED functionaries had been troubled by a significant presence of students who did not 'belong to us', that is, students of bourgeois background. ${ }^{26}$ They learned that the most efficient way of binding students to the Party was through scholarships. Students who became materially dependent on the Party tended to behave loyally. The wisdom of this policy was shown in 1956 when trouble tended to emanate from groups not dependent upon stipends, such as future veterinarians. ${ }^{27}$

Table 2. Worker and peasant students at Czech, East German and Polish universities

\begin{tabular}{llllll}
\hline \hline & $\begin{array}{l}\text { Czech Lands } \\
\text { (student body) }\end{array}$ & (CSSR) & $\begin{array}{l}\text { GDR } \\
\text { (student body) }\end{array}$ & $\begin{array}{c}\text { Poland } \\
\text { (freshmen) }\end{array}$ (graduates) \\
\hline $\mathrm{I} 947 / 8$ & $18.0^{28}$ & & $16.8^{29}$ & $41.7^{30}$ & \\
$\mathrm{I} 949 / 50$ & & 37.5 & 34.0 & $45.6^{31}$ & \\
$\mathrm{I} 950 / \mathrm{I}$ & $36.8^{32}$ & 44.0 & 38.6 & $62.2^{33}$ & \\
$\mathrm{I} 952 / 3$ & & $4 \mathrm{I} \cdot 5^{34}$ & 45.4 & $59.4^{35}$ & \\
$\mathrm{I} 953 / 4$ & 37.3 & $41.4^{36}$ & 48.1 & 57.8 & 58.9 \\
$\mathrm{I} 956 / 7$ & 38.4 & $43.8^{37}$ & 57.1 & 48.5 & 56.4 \\
$\mathrm{I} 960 / 1$ & 37.8 & $43.6^{38}$ & 56.0 & 44.5 & 53.4 \\
$\mathrm{I} 96 \mathrm{I} / 2$ & 39.6 & 45.7 & 55.0 & 44.6 & 49.7 \\
\hline \hline
\end{tabular}

25 In June 1950 Ulbricht demanded that the intake for worker-peasant faculties that year be increased from $\mathrm{I}, 500$ to 4,500 . BAAP, $\mathrm{C}_{20} / \mathrm{IO}_{\mathrm{I} 9} / 82-\mathrm{s}$. For other records of Ulbricht's extraordinary activism see ibid., C20/I6, C20/IOII; R2/I892/76, II54/I, II25/IIs, I478/252; R3/223/S; EI/ 17085/60-92, 17514/6; SAPMO-BA ZPA NL 182/933; IV2/9.04/465.

26 See, for example, the comments of Professor $W$. Hauser at 'Vierte Tagung des zentralen Hochschulausschusses der SED am 7. und 8. Februar I948', SAPMO-BA, ZPA IV2/9.04/6 (unnumbered), $24 \mathrm{I}$.

27 Richert, Hochschulpolitik, 133 .

28 These figures may be inflated because they include everyone employed in the agricultural sector. The percentages of workers only among the student body in $1946 / 7$ and $1947 / 8$ were 7.2 and 6.7, respectively. SÚA ÚPV I I IO, C. 2 I 1894/48.

29 Herbert Stallmann, Hochschulzugang in der SBZ/DDR (Sankt Augustin: Richarz, 1980), 305-7.

30 AAN MO/2869/47-50.

31 Statystyka szkolnictwa, Aug. 1966, 40.

32 SÚA - AÚV KSC̈, f. I0o/I a.j. I Is5/I17.

33 AAN MSW I 7/91-2.

34 SÚA - AÚV KSČ, f. 19/7, a.j. 280/96.

35 Statystyka szkolnictwa, Aug. 1966, 40.

36 SÚA ÚPV 248 I.

37 Statistická roćenka Republiky Ćeskoslovenské 1957 (Prague: Orbis, 1957), 238. The differences in Czech and Czechoslovak totals are explained by the influx of students of peasant background into the Slovak student body.

38 Statistická ročenka Československé Socialistické Republiky 1962 (Prague: Státní nakladatelství technické literatury, 1962), 419. 
Table 3. Percentage of students receiving state stipends

\begin{tabular}{|c|c|c|c|c|}
\hline & Czech Lands ${ }^{39}$ & $\check{C S S S R}^{40}$ & Poland ${ }^{41}$ & $\mathrm{GDR}^{42}$ \\
\hline $1951 / 2$ & 49.4 & & & 88.0 \\
\hline $1952 / 3$ & 48.7 & & & 92.0 \\
\hline 1954 & & 46.2 & & 95.2 \\
\hline I955 & & 56.3 & 71.0 & 88.4 \\
\hline I956 & & 55.2 & 65.5 & 90.7 \\
\hline 1957 & & 41.8 & 60.5 & 87.8 \\
\hline I958 & & 32.3 & SS.I & 94.0 \\
\hline 1959 & & 23.0 & 51.2 & 90.6 \\
\hline I960 & & 22.1 & 53.3 & 89.2 \\
\hline I96I & & $2 \mathrm{I} .4$ & & 88.8 \\
\hline 1965 & & 30.3 & 47.5 & 84. I \\
\hline I968 & & 38.7 & 41.9 & 90.0 \\
\hline 1969 & & 44.8 & $45 \cdot I$ & \\
\hline
\end{tabular}

In $1958 / 9$ all East German worker-peasant students (S5.I per cent of the total) received full scholarships; the remaining scholarship holders received a two-thirds stipend. In Poland, at the same time, thirty-nine per cent of students received a full stipend and 4.7 per cent a partial stipend. ${ }^{43}$ There was in Poland and Czechoslovakia additional scholarship aid from enterprises, but nowhere was the state so directly responsible for student welfare as in East Germany.

The East German Party had been most careful to bind students into a web of dependency and obligation. There were relatively more taken from the lowest social groups; they were given the longest and most expensive pre-university preparation and the highest state stipends, and were made to join Communist organisations. As early as the winter term $1946 / 7$, close to one-third of the students of the Soviet Zone of Occupation were SED members. ${ }^{44}$ All of this formed the basis for a highly effective system of reward and punishment. The Polish Party achieved only partial success: many of the students came from a peasant background, but not as many received stipends or became attached to the Party. In I953 barely nine per cent of Polish students had become members of the PZPR; by 1958 that total declined to

39 SÚA AÚV KSČ́ f. $19 / 7$ a.j. 280/95.

40 Historická statistická ročenka ĆSSR, (Prague: SNTL - Nakladatelstvi technické literatury, I985), 595, 597 .

${ }_{41}$ Rocznik statystyczny 1960 (Warsaw, 1960), 357; Rocznik statystyczny 1970 (Warsaw, 1970), 423, 439.

42 Statistisches Jahrbuch der Deutschen Demokratischen Republik 1960/61 (Berlin, 1961), 133; Statistisches Jahrbuch der Deutschen Demokratischen Republik 1970 (Berlin, 1970), 386.

43 Wemer Kienitz, (ed.), Das Schulwesen sozialistischer Länder in Europa (Berlin: Volk und Wissen, 1962), 266-7, 352 .

44 BAAP, R2/1060/46; Kasper, 'Der Kampf', 272. 
2.5 per cent. ${ }^{45}$ Worse still, they entered unreformed university environments: in I954 II.I per cent of Polish professors (full and extraordinary) belonged to the Party. ${ }^{46}$ That same year 28.8 per cent of East German professors belonged to the SED. ${ }^{47}$ The Polish total stagnated while the East German steadily rose.

The growing numbers of worker-peasants in East German universities are all the more impressive given the relatively small agricultural sector in that country. Places like Bulgaria, Slovakia and Poland, where much of society was moving from village to town, found it much easier to recruit new élites from underprivileged classes. As the Czech statistics indicate, transforming the 'ruling class' into an intermediate stratum was not so simple. ${ }^{48}$ Though more than a fifth of the university students in the Czech Lands in the early I95os belonged to the KSČ few came from worker or peasant backgrounds and therefore did not owe social advancement to the Party. ${ }^{49}$ After the mid-I950s the regimes in Hungary, Poland and Czechoslovakia gradually abandoned affirmative action programmes. ${ }^{50}$ Though numbers of worker-peasant students began to decline in East Germany as well, they remained high, and the enticements extended relatively the furthest.

The political fruits of this attention were visible during the crisis of June I953. The uprising of that month was a working-class affair: ${ }^{51}$ students, who played leading roles in similar popular outbursts in later years in Poland, Hungary and Czechoslovakia, had little to do with the events of that month. ${ }^{52}$ At worst, internal SED memoranda criticised students for having behaved too passively on the day:

45 Piotr Hübner, Nauka polska po II wojnie światowej - idee i instytucje (Warsaw: Centralny Ośrodek Metodyczny Studiów Nauk Politycznych, 1987) 1 34, I 73; Barbara Fijalkowska, Polityka i twórcy (19481959), (Warsaw: PWN, 1985), 464.

46 Hübner, Nauka, I74. In I958 the number of Polish professors and docents belonging to the Party was I 1.4 per cent. Fijalkowska, Polityka, 464.

47 Ralph Jessen, 'Professoren im Sozialismus. Aspekte des Strukturwandels der Hochschullehrerschaft in der Ulbricht-Ära', in Harmut Kaelble, Jürgen Kocka and Harmut Zwahr (eds.), Sozialgeschichte der DDR (Stuttgart: Klett, 1994), 241.

48 John Connelly, 'Students, Workers, and Social Change: The Limits of Czech Stalinism', Slavic Review, Vol. 56, no. 2 (1997). On the central role of former peasants in East European Communist élites see Zygmunt Bauman, 'Social Dissent in the East European Political System', in Bernard L. Faber (ed.), The Social Structure of Eastem Europe (New York: Praeger, 1976), 129.

49 This figure pertains to students of Charles University in Prague and Masaryk University in Brno. SÚA-AÚV KSĆ, f. 02/4, a.j. I 20, bod i 9 .

50 The Polish regime mostly scrapped the affirmative action policy in 1955, though there was a brief resurgence after 1965 . Jan Osinski, 'Zasada preferencji spolecznej jako metoda przyspieszenia demokratizacji wyższego wykształcenia', in Magdalena Roszkowska, ed., Rekrutacja mł̇odziezy na studia wyższe (Warsaw: PWN, 1973), 199. In Hungary, the class-based quota system was relaxed in the midr9sos. Sonija Szelényi and Karen Aschaffenburg, 'Inequalities in Educational Opportunity in Hungary', in Yossi Shavit and Hans-Peter Blossfeld (eds.), Persistent Inequality: Changing Educational Attainment in Thirteen Countries (Boulder, CO: Westview, 1993), 274, 295.

51 Jürgen Kocka and Martin Sabrow (eds.), Die DDR als Geschichte (Berlin: Akademie Verlag, 1994), $54-5$.

52 Anke Huschner, 'Der 17. Juni 1953 an Universitäten und Hochschulen der DDR', Beiträge zur Geschichte der Arbeiterbewegung, no. S (199I), 682; Ilko-Sascha Kowalczuk, 'Volkserhebung ohne "Geistesarbeiter?" Die Intelligenz in der DDR', in Ilko-Sascha Kowalczuk, Armin Mitter and Stefan Wolle (eds.), Der Tag X 17. Juni 1953 (Berlin: Linksverlag, 1996), 153-7. 
they had not shown enough vigour in opposing strikers and demonstrators. ${ }^{53}$ In only a few cases were students reported as having joined strike committees; in many more they had worked to keep production going. ${ }^{54}$ During a 1954 retrospective, the State Secretary for Higher Education, Gerhard Harig, recommended expanding worker-peasant education, because the 'overwhelming majority' of students had acted 'exemplarily' during the challenges of the previous year. ${ }^{55}$

The Party also treated the older generation of intellectuals with a mixture of suppression and coddling. Faced with restrictions on scholarship and often with the threat of arrest, leading 'bourgeois' social scientists like Hans Freyer, Walter Hallstein, Hans-Georg Gadamer, Eduard Spranger, Theodor Litt and Hans Leisegang had emigrated by 1948 . Those who remained were gradually joined by a distinguished group of leftist intellectuals including Walter Markov, Hans Mayer, Ernst Bloch, Hermann Budzislawski and Wieland Herzfelde. As is well known, many of the most celebrated German writers also chose to live in the East. If they remained loyal, intellectuals in East Germany could be treated to salaries that exceeded a worker's fifty-fold. ${ }^{56}$ In addition, university professors retained substantial powers within their institutes. These facts may have desensitised them to contradictions in the world around them. ${ }^{57}$ In Poland, by contrast, the bounty could not be spread so thickly; most professors were forced to hold several jobs just to make ends meet. ${ }^{58}$ Professors in the Czech Lands were so neglected that Soviet advisors had to encourage the authorities to raise their salaries so that progress might be made in filling vacant slots. ${ }^{59}$ In the GDR, policies towards students and

53 The SED higher education functionary Franz $X$. Wohlgemuth reported at the first rectors conference after 17 June that 'there have been no disorders [Unruhen] at any universities'. BAAP, R3/ I $538 / 30$. In Halle there were some extraordinary cases of students taking part in demonstrations, but in general one can say that the university and its members showed their good side during the events of 17 June 1953'. In Berlin, many students 'show[ed] a positive atcitude either by turning away from the demonstrations, or by discussing with the demonstrators instead of joining them'. BAAP $\mathrm{R}_{3} / 1_{47 / 28-}$ 34.

54 Huschner, 'Der I7. Juni', 690-1.

55 Speech of 5 July 1954, in Hans-Joachim Lammel (ed.), Dokumente zur Geschichte der Arbeiter-undBauem-Fakultäten der DDR, II: 1949-1966 (Berlin: Institut für Hochschulbildung, 1988), 1 $30-43$.

56 By January I952, over I 4,000 'individual contracts' of up to 20,000 marks monthly had been concluded with 'members of the intelligentsia'. The average monthly wage in the GDR at that time was 308 marks. Ilko-Sascha Kowalczuk, 'Die Durchsetzung des Marxismus-Leninismus in der Geschichtswissenschaft der DDR (1945-1961)', in Martin Sabrow and Peter Th. Walther (eds.), Historische Forschung und sozialistische Diktatur: Beiträge zur Geschichtsurssenschaft der DDR (Leipzig: Leipziger Universitätsverlag, 1995), 53. In 1953, over 20 per cent of professors had individual contracts, and workers believed that they also benefitted from special shops [Intelligenzläden]. Huschner, 'Der I 7. Juni', 682.

57 Hans Mayer, for example, was taken daily to and from university by taxi - an unimaginable luxury for Leipzig the early I9sos. Andreas Krzok, 'Erinnerung an Leipzig', in Inge Jens, (ed.), Über Hans Mayer (Frankfurt am Main: Suhrkamp, 1977), 126.

58 RFE Report, Item no. 353/57; Czesław Luczak (ed.), University of Poznań 1919 - 1969 (Poznań: Drukamia Uniwersytetu im. A. Mickiewicza, 1971), 255.

59 See the letter of Soviet Professor P.M. Bidulya to Z. Fierlinger in SÚA AÚV KSČ fo. 19/7 a.j. 272/99-103, and the report of a trip in the spring of 1953 of Czechoslovak higher education experts to the Soviet Union, in ibid., f. 19/7, a.j. 272/2 1 36-43. 
professors ultimately merged, as in the I970s the graduates of worker-peasant faculties began populating teaching staffs. ${ }^{60}$

As with students, the older generation of intellectuals behaved passively or loyally during the I953 crisis. Leading figures of the I956 intellectual challenge to the SED even welcomed the Soviet forces. Bertold Brecht cheered from his balcony as Soviet tanks entered the Friedrichstrasse. Economist Fritz Behrens ordered a tram driver to remove a 'provocative flag' from his vehicle before allowing the ride to commence. In many cases, professors acted to secure university buildings. ${ }^{61}$ Ernst Bloch's son Jan Robert recalled that his father and other beacons of opposition to the SED failed to become seriously interested in the workers' uprising of 17 June. ${ }^{62}$ Former emigrés from Nazi Germany were highly suspicious of spontaneous mass street activity. Bloch's friend, the professor of literature Hans Mayer, saw in the demonstrators not workers but a fascist mob: 'In 1933 or 1938 the murderers wore brownshirts. Now they wear Wild West costumes. ${ }^{\text {' } 3}$

\section{The Interrupted Thaw}

Despite the evident success of its policies towards the intelligentsia in June I953, the regime could not continue as if nothing had happened. Intellectuals had behaved passively at worst, but they were not entirely content. There had been expressions of understanding, if not solidarity, for workers and, more importantly, of desires for greater freedom in research and writing. ${ }^{64}$ Professors bemoaned the growing regimentation of scientific research and the difficulties of attending conferences in the West. Students likewise criticised reforms which had imposed a set schedule of classes and robbed them of summer holidays. Massive suppression of tiny Protestant youth groups in 1952 also gave rise to a general feeling of unease. ${ }^{65}$

The SED's response to the dissatisfaction among intellectuals was a more liberal 'New Course' in cultural affairs. The Party permitted relatively open and critical discussions at universities throughout the summer of 1953 . For example, a meeting of university rectors in July could demand that the government respect its own laws. ${ }^{66}$

60 In I95 I 7.7 per cent of East German professors were of working-class background, and 23.1 per cent belonged to the SED. In 1971 the figures were 39.1 per cent and 6r.5 per cent respectively. Ralph Jessen, hochschule ost, no. 3 (1995), 70.

${ }_{61}$ Huschner mentions Halle and Jena, 'Der 17. Juni', 690.

62 Hans-Dieter Zimmermann, Der Wahnsinn des Jahrhunderts. Die Verantwortung der Schriftsteller in der Politik (Stuttgart: Kohlhammer, 1992). Yet they also found that workers possessed some legitimate complaints. See esp. the comments of Emst and Karola Bloch, in SAPMO-BA, ZPA IV 2/9.04/426/ 93-95.

63 SAPMO-BA, ZPA IV 2/9.04/426/97-9.

64 On professors' understanding for workers' demands, see the comments on rector Hämel of Jena. Huschner, 'Der 17. Juni', 690.

65 Waldemar Krönig and Klaus-Dieter Müller, Anpassung Widerstand Verfolgung. Hochschule und Studenten in der SBZ und DDR 1945-1961 (Cologne: Verlag Wissenschaft und Politik, 1994), 364-93.

66 BAAP R $3 / 6323 / 1_{3}$, 19. Later, there would be reports of 'openly hostile attitudes' expressed at the general meeting of members of the University of Leipzig on 25 July 1953. 'Entwurf einer Entschliessung der PO der Institute f. Philosophie und Psychologie der KMU Leipzig', BAAP R 3 / 4230. 
The new atmosphere absorbed the intellectuals' grievances but, more importantly, it provided SED hardliners a chance to regroup, with Soviet endorsement. Whereas the Soviets had driven a wedge in the Hungarian leadership after Stalin's death, the events of 17 June convinced them that only Ulbricht could maintain order in East Germany, and therefore they supported his position.

Internal party reports noted that a 'fundamental improvement of Party work took place after the [summer] holidays' of $1953 .{ }^{67}$ By early 1954 , the more daring voices of criticism had fallen silent, accused of insisting on 'discussions of mistakes' (Fehlerdiskussionen). Organisations of young Christians again came under heavy fire, though without the deafening barrages of 1952. The Party proceeded more quietly, and also more effectively. Rather than permitting semi-independent discussion clubs to emerge within the Party, the leadership pulled tight 'transmission belts' such as the 'Cultural Union for Democratic Rebirth' (Kulturbund), which 'organised' I 70,000 intellectuals and artists. In February 1954, the second secretary of the Kulturbund, former Gulag inmate Erich Wendt, affirmed that intellectuals could not be denied the right to association, but it was better that they meet at the Kulturbund rather than 'in pubs, tea parlours or with Kaffeekränzen . . . in the old caste spirit'. ${ }^{68}$ The fall of Malenkov early in 1955 meant a momentary end to any thoughts of liberalisation, though officially the New Course was not retracted. When asked what the New Course meant, Walter Ulbricht could now answer simply 'MarxismLeninism'.69

The year 1956 therefore caught both the East German regime and East German intellectuals off guard. Although debates had been raging in Polish and Hungarian cultural institutions, the East German scene remained bleak. This was most apparent at meetings of East German with other Eastern European intellectuals. In May 1955, delegations from across Eastern Europe travelled to Weimar to commemorate the I soth anniversary of Schiller's death. Professor of German literature Alfred Kantorowicz (SED) confided his impressions to his diary:

Discussion with Polish, Hungarian and Czech writers, professors, graduate students. The agreement is stunning. What they say about the ferment of all classes [Volksschichten] of their countries against the stubborn dictatorship of the Party functionaries reminds me of the mood around 17 June 1953. It makes one hopeful as well as depressed. The Polish and Hungarian writers have achieved more freedom of movement through their struggle against the cultural functionaries than we have. They have public debates in which the writers are

67 Ibid. This report from early 1954 is typical of the retum to the Stalinist practices of intimidation and crushing of dissent. Now it was noted that 'the Party organisation stands unanimously behind the Central Committee decisions and thanks the Central Committee for the annihilation of the traitorous Herrnstadt-Zaisser Group'.

68 Magdalena Heider, Politik-Kultur-Kulturbund: Zur Gründungs- und Frühgeschichte des Kulturbundes zur demokratischen Emeuerung Deutschlands 1945-1954 in der SBZ/DDR (Cologne: Verlag Wissenschaft und Politik), I 84. In 1956 Ulbricht would demonstrate a similar adeptness at staying one step ahead of a popular mass movement by himself inaugurating the formation of 'workers' councils', fearing that East German workers might follow the Hungarian example. Stefan Heym, Nachnf (Berlin: Der Morgen, 1990), 605-6.

69 Walter Markov, Zuiesprache mit dem Jahrhundert. Dokumentient von Thomas Grimm (Cologne: Volksblatt, 1990), 208. 
like a bloc in their opposition to the bumbling attempts of Party bosses to interfere in literary affairs.

Here they had occasion to take part in a conference of the chiefs of our 'writers in uniform' ['kasernierte Schriftstellerei', i.e. the East German Writers Union]. . . . Afterwards we met ... N. said: 'the way they sat there, Kuba [Kurt Bartel] and Claudius and a few other members of the board of your Writers' Union, with their swollen necks, fists resting on the table, and with an expression as if to say: "Do as you like. We have everything under control. No, that would be impossible in our country." (I wrote this sentence down verbatim.) Everyone agreed. I had nothing to say. ${ }^{70}$

Leading figures of the East German Writers' Union had survived the Moscow purges of two decades earlier, and, as Minister of Culture Johannes $\mathrm{R}$. Becher wrote of himself, "when your backbone has been broken, no one will persuade you to stand straight again'. ${ }^{71}$ In Poland and Hungary, younger writers set the tone in 1956; in East Germany famed figures of the older generation such as Friedrich Wolf, J. R. Becher, Wieland Herzfelde, Amold Zweig, Willi Bredel and Anna Seghers remained powerful and hindered debate. ${ }^{72}$

Writer Gerhard Zwerenz described the scene in Leipzig, a place otherwise famous for intellectual vitality: 'Until i956 our life at the university was bland and boring. ${ }^{73}$ Even after Khrushchev's revelations SED controls remained stifling. If in Hungary or Poland intellectuals were a bloc, in Leipzig the bloc was the Party: 'News came into the country via western stations, and people began to know what had been said, yet when comrades came together they acted as if nothing had happened. Only people with great trust in each other confided in whispers what was moving them. The Party remained like a block of granite. ${ }^{74}$

\section{6 and the Students}

The SED leadership felt such confidence in its students that it even dared provoke them. In I955, the ancient medical faculty of Greifswald University was informed that it would be converted into a military medical academy. Students who chose to remain would become army officers. Soon after this announcement, rumours of a strike began to circulate around the university. Yet, before any would-be dissenter could lift a finger, the SED called the medical students to the university's main hall for a 'meeting' with Mecklenburg's SED boss, Karl Mewis. As the 'meeting' was about to start, Mewis alleged that a student had struck him, and used this 'provocation' to trigger the mechanisms of repression. Over 250 students were quickly transferred from the university auditorium to a nearby jail. Most were released gradually over the next few days and weeks, but several students who had

70 Deutsches Tagebuch, zweiter Teil (Munich: Kindler, I96I), 553.

71 See Pike, Politics, $x$.

72 On the behaviour of these 'writers in uniform' in comparison with that of Hungarian writers, see Kantorowicz, Deutsches Tagebuch, zweiter Teil, 682.

73 Horst Krüger (ed.), Das Ende einer Utopie: Hingabe und Selbstbefreiung früherer Kommunisten (Freiburg: Walter-Verlag), 183.

74 Gerhard Zwerenz, Der Widerspruch. Autobiographischer Bericht (Berlin: Aufbau, 1991), 237. 
been identified as ringleaders spent years in jail. A fully 'peaceful' conversion of the medical faculty then took place. ${ }^{75}$

For the SED leadership, it was not enough to have stifled dissent where it emerged. Rumours of the planned strike in Greifswald had floated throughout the East German university world, and provided the SED with an occasion to impose even greater control. At the beginning of the summer term, authorities at East Berlin's Humboldt University decided to make an example of one student who had spoken critically about the Greifswald affair. He was put on trial by the university Party leadership, and saved only by the resourcefulness of his professor. But the 'example' had been made. ${ }^{76}$

Despite such aggressive policies, I956 became a year of consternation for the Ulbricht leadership. It could not sense how far the de-Stalinisation inaugurated at the Twentieth Party Congress would go. For a brief period, the unity of the leadership itself seemed to be in question. Leading functionaries Ernst Wollweber (security), Karl Schirdewan (cadres), Kurt Hager (ideology) and Paul Wandel (culture) are all thought to have favoured some degree of liberalisation. Before the final showdown in Budapest, Otto Grotewohl even promised artists greater freedom and students some revision of the obligation to learn Russian. ${ }^{77}$ Ulbricht may have felt particularly uncomfortable because he had kept faith with Stalinism to the last. He was therefore careful to circumscribe the effects of Khrushchev's condemnations. Resolutions were prepared announcing that there had never been a 'cult of personality' in East Germany. ${ }^{78}$ Ulbricht even chided younger comrades who had gone too far in their devotion to Stalin, for example by learning his writings by heart. He neglected to mention that they had done so under his direction.

Such prevarications enraged the SED faithful at the universities, and mid- to late I956 became a time of intense discussion. Because of scant East German media coverage of events in the Soviet Union, East German Communist intellectuals found themselves doing what was once unthinkable: tuning into Western news broadcasts. Such direct access made them some of the best informed intellectuals in East Central Europe. In May the secret police (Stasi) reported that:

At almost all universities heated and extensive discussions of the Twentieth Party Congress are taking place. . . . There was, however, a noticeable failure among the students of many faculties (e.g. the institutes of the philosophical faculty in Leipzig) to give priority to deliberating the harmfulness of the cult of personality; rather, students were out for sensation, and eagerly noted and discussed all published mentions of Stalin's mistakes.

Students hoped that a change of leadership would take place in the SED as it had in other East European parties, yet unlike counterparts in Warsaw, Prague, Bratislava or Budapest, they failed to demand solutions to more than specifically student grievances: too much Russian language, compulsory instruction in

Krönig and Müller, Hochschule, 288.

Kantorowicz, Tagebuch, 544.

Neues Deutschland, 3 Nov. 1956, cited in Richert, Hochschulpolitik, 139.

78 These were to be accepted at university SED organisations without deliberation. Kantorowicz, Tagebuch, 603 . 
Marxism-Leninism, travel restrictions. ${ }^{79}$ In May 1956 the Stasi reported that students in Greifswald were demanding a curtailment of ideological indoctrination; counterparts in Rostock and Jena concentrated complaints upon Russian language instruction. The single concrete achievement was a withdrawal of travel restrictions after a demonstration by almost 1,000 students in Dresden. Yet those restrictions were quietly reinstated a year later. ${ }^{80}$

Despite their carefully limited character, the SED leadership took challenges from students seriously, and even in this time of uncertainty attempted to stifle hints of disagreement, whether serious or farcical. Imagining that they might take advantage of the more open atmosphere, several hundred students of the Music Academy in Weimar staged a mock demonstration in the centre of the town, protesting about the music of the popular folk singer Herbert Roth, whom they satirised as a 'serious danger for true folk music'. Their 'demonstration' was quickly suppressed and an investigation was launched to find the supposed instigators. The matter even reached the Politbureau, where Walter Ulbricht lamented that 'no one could find out' who had put up the notice on the bulletin board calling for this demonstration. 'This shows that the enemy can surprise us right in the centre of our own country, and we know nothing about it. 81

The summer vacation interrupted the formation of oppositional sentiments among students. Yet soon after they returned to university in the autumn, the Stasi reported 'agitated discussions' of the events occurring in Poland and Hungary. Students mocked the government's restrictions on the flow of information from Poland, for example by confiscating copies of an East Berlin newspaper which had prominently featured Gomułka and part of his acceptance speech. The Stasi observed students getting first-hand knowledge of events in Poland at East Berlin's Polish cultural centre and students of Slavic languages translating news fron Trybuna Ludu. ${ }^{82}$

Yet open and organised activity was almost entirely limited to the medical and veterinary faculties. These were the faculties with the fewest worker-peasant students, and the most 'bourgeois professors' who could still provide students with 'traditional role models'. The threatened withdrawal of scholarships may have pacified students of other faculties, but these 'bourgeois' students often had alternative sources of income. For example, veterinary students could earn money by taking part in immunisation campaigns. Their subjects of study had also been among the most resistant to ideological penetration. ${ }^{83}$ Further separating these

79 Mitter and Wolle, Untergang, $23 \mathrm{I}$.

80 Krönig and Müller, Hochschule, 294-5. On the re-instatement see Aktennotiz für Gen. Hager, 4. Juni 1956. SAPMO-BA, ZPA IV2/9.04/46/19-2I; Politbureau meeting of 23 April i957, in SAPMO$\mathrm{BA}, \mathrm{ZPA} I \mathrm{~V}_{2} / 2 / 538$.

81 Mitter and Wolle, Untergang, 233.

82 Ibid., 263.

83 Richert, Hochschulpolitik, 133. For the greater personal continuity among professors of medical faculties, see Ralph Jessen, 'Vom Ordinarius zum sozialistischen Professor. Die Neukonstruktion des Hochschullehrerberufs in der SBZ/DDR, 1945-1969', in Richard Bessel and Ralph Jessen (eds.), Die Grenzen der Diktatur: Staat und Gesellschaft in der DDR (Göttingen: Vandenhoeck and Ruprecht, 1996), 92-3. 
students was the Soviet-style method of instruction, which kept students of differing specialisations apart. Thus it was possible for students of Kantorowicz's Institute of German Literature in Berlin to support a resolution condemning the actions of students in the medical faculty. ${ }^{84}$

But even medical students did not intend to mount a political challenge. In the last week of October their activities climaxed in their demands for an end to Marxist-Leninist indoctrination, Russian language instruction and the Soviet-style ten-month academic year, as well as for the right to matriculate freely and form independent student representation. The only demand that transcended direct student concerns was for more open media coverage. ${ }^{85}$

The sole attempts at public demonstrations originated in Berlin's medical faculty. On 24 October, shortly after Gomułka's accession to power in Poland and at the beginning of the armed conflict in Hungary, there was a call to a protest march at Marx-Engels Platz. Ulbricht, perhaps heartened by reports of Soviet intervention in Hungary, now recovered his determination. The students never reached the wouldbe demonstration, because the SED leader had them incarcerated for two days in the university building where they had been debating.

These efforts at intimidation were not immediately successful, however. On 3 November, students meeting at the veterinary faculty demanded an end to Russian language and 'social science' instruction, an expanded student exchange within Germany, unrestricted travel and better access to Western scientific literature. Students called for a march to proceed from the border with West Berlin to the nearby State Secretariat for Higher Education. About I, ooo would-be demonstrators met at the appointed hour, but instead of taking their demands eastwards, they were pushed back into West Berlin by the People's Police. This was only the most visible manifestation of a pervasive phenomenon: namely, the draining of East German protest potential to the West.

This proved to be the last open expression of dissent among students. News of the suppression of the Hungarian uprising caused a sea change in East German politics as, in the words of Erich Loest, 'from one week to the next functionaries rediscovered the certain old hardness and hard old certainty of their language and arguments' ${ }^{86}$ Large contingents of "workers" militias accompanied SED leaders to meetings with students in Berlin in the first days of November; when the "workers" turn came to speak they thundered their 'outrage' at the students' demands; the 'workers' after all had made university education possible to begin with. In a meeting with Berlin's academic senate on 3 November, Kurt Hager complained of the difficulty he had in holding back workers who wanted to 'beat up' (zusammenschlagen) students. ${ }^{87}$ After this, several small student discussion groups emerged in Jena, Halle and Magdeburg which were systematically destroyed in the closing years of the decade. ${ }^{\mathbf{8}}$

Richert, Hochschulpolitik, 142.

Mitter and Wolle, Untergang, 265; Richert, Hochschulpolitik, I 37.

Durch die Erde ein Riss. Ein Lebenslauf (Leipzig: Linden-Verlag, I990), 288-9.

Kantorowicz, Tagebuch, 684, 686-8; Krönig and Müller, Hochschule, 29 I-2.

Beginning in early 1957, a group of seven to eight students formed in Halle for free discussion 


\section{'Revisionism'}

The most significant intellectual challenge emerged only after the Ulbricht regime recovered its sense of mission in the wake of the Hungarian revolution. The challenge emanated from young Party members associated with the cultural journal Sonntag, the Aufbau publishing house, and Leipzig and Berlin universities. As with counterparts elsewhere in East Central Europe these 'revisionist' Marxist intellectuals desired a reform of socialism, and took inspiration from the Yugoslav model: workers' councils, multi-candidate elections, profit-sharing for workers, an end to collectivisation and greater intellectual freedoms. Their ostensible leader, the brilliant young philosopher Wolfgang Harich, hoped in addition to achieve German unity through a joint SED-SPD platform. ${ }^{89}$

What made East German revisionists stand out against an East Central European background was not so much their ideas as their activities. These were characterised by unwavering loyalty to the Party. How these intellectuals imagined change to be possible without direct challenges to Ulbricht remains a mystery. Having worked for years in the Party they knew of its strict centralisation and hierarchical character, yet they refused to consider allies outside or even within the Party leadership: ${ }^{90}$ neither they nor Ulbricht's Politbureau rivals considered making common cause. ${ }^{91}$

As loyal Party soldiers, East German revisionists wished not to be seen to be a faction, and they therefore ignored the rules of conspiracy. Perhaps the most important meeting of would-be opponents - the November 1956 gathering of editors Walter Janka, Gustav Just, Heinz Zöger with Wolfgang Harich, and Paul Merker in Klein-Machnow near Berlin - agreed to do nothing in order not to 'endanger the unity of the Party'. ${ }^{92}$ Harich openly confided his plans to the Soviet Ambassador and to Ulbricht himself, and failed to consult his closest associates before under-

of 'political and world view problems'. They were moved by the 'growth of intolerance in political life after the suppression of the Hungarian Uprising'. Two of the founders were sentenced to seven years in prison for 'state treason'. Krönig and Müller, Hochschule, 296-300. In 1958 four students in Magdeburg were given prison sentences of several years for protesting at the founding of a medical academy there. Ibid., 30o. A group of students formed in Jena in 1954 at the Eisenberg high school, and considered themselves a true resistance group in the tradition of Stauffenberg. They continued meeting as students in Jena, until discovered in 1958. Ibid., 30I-4. In 1959, a trial took place in Dresden of five students of the Technical University who had formed a school group in 1956 to protest the limitations on political freedom. They received a sentence of five to ten years. Ibid., 305-8. On Eisenberg, see also Patrik von zur Mühlen, Der 'Eisenberger Kreis': Jugenduiderstand und Verfolgung in der DDR 1953-1958 (Bonn: Dietz, 1995).

Loest, Durch die Erde, 298; Croan, 'Revisionism', 246-7; Richert, Hochschulpolitik, i so.

90 Gustav Just, Zeuge in eigener Sache. Die fünfziger Jahre (Berlin: Der Morgen, I990), I0I-2.

91 Ulbricht's major rival, Karl Schirdewan, claims to have represented a socialist alternative to Ulbricht. See his Aufstand gegen Ulbricht: Im Kampf um politische Kurskorrektur, gegen stalinistische, dogmatische Politik (Berlin, I994), I00, II4. Yet, in the decisive days of 1956, he played the resolute hardliner, telling students that to advocate change to 'social science' revealed a 'reactionary petty bourgeois lifestyle'. Richert, Hochschulpolitik, I 38.

92 Ibid., r 108-9. For Janka's recollections, see Schwierigkeiten mit der Wahrheit (Reinbek: Rowohlt, 1989). Harich's response is Keine Schwierigkeiten mit der Wahrheit (Berlin: Dietz, 1993). 
taking his spectacular trip to Der Spiegel in Hamburg. ${ }^{93}$ Any group cohesion - for example of 'the Harich-Janka group' - was an invention of Walter Ulbricht for use at trials that would intimidate other intellectuals. Such behavior very much contrasts with that of their Polish counterparts, for whom conspiracy and faction formation were ways of life, inherited from generations of foreign occupation.

After the summer of 1956, Ulbricht never lost the initiative. Events in neighbouring countries had reinforced his conviction of the danger of intellectuals. The SED leadership decided that there was 'an organic agreement of the counterrevolutionary ideology' of East German revisionist intellectuals with that of the 'hostile' groups in Hungary and Poland. This could be explained only by the 'unified direction at the hand of the [class] enemy'. 94 Despite its fundamental subservience, Ulbricht therefore subjected the East German intelligentsia to waves of repression. The Western press tended to magnify his concerns, facilely identifying Bloch as the German Lukács and Harich as the German Kołakowski. ${ }^{95}$

In November 1956, Harich became Ulbricht's first victim. He was accused of 'relations with the reactionary Petöfi cịcle in Hungary'. ${ }^{96}$ After thanking the Stasi for arresting him, Harich proved willing to co-operate fully in the Party's destruction of his mentors and friends, and implicated in particular Janka and Bloch. He reported, for example, that Bloch 'throughout the year 1956 worked himself into a position directly hostile towards the SED leadership'. ${ }^{97}$ The next victims of the crackdown were Janka and his colleagues from the cultural weekly Sonntag, Gustav Just and Heinz Zöger.

Ulbricht then turned his attention to the circle around Ernst Bloch in Leipzig, where there had been vigorous discussions among young writers and students. ${ }^{98}$ According to writer Gerhard Zwerenz, in early 1956 the 'old Stalinists withdrew in confusion and indignation' and made no attempt to hinder the revisionists' activities. ${ }^{99}$ Yet in the autumn, the bureaucrats' confidence returned and this 'group' quickly dissolved. ${ }^{100}$ In March 1957 , Ernst Bloch was compulsorily retired. His remaining students were 'strongly advised' to renounce their master. Some did, like Hans Pfeiffer. Jürgen Teller did not and, in order to prove his worthiness, was sent to 'production' where an accident cost him his right arm. Günter Zehm also

93 Gerhard Zwerenz has called Harich an 'adventurer'. Der Widerspruch, 2 I 2-3.

94 SAPMO-BA IV/2/1/183/18ff: Cited in Mitter and Wolle, Untergang, 288. For the judgement that Ulbricht 'overreacted', see Karl Wilhelm Fricke, 'Widerstand und Opposition von 1945 bis Ende der fuinfziger Jahre', in Materialien der Enquete-Kommission, Vol. 7, 24.

95 For SED reports on Harich and Bloch, with copious and annotated Western press cuttings, see SAPMO-BA, ZPA IV 2/9.04/162-3.

96 In the words of Kantorowicz, to mention the Petöf-Club 'called forth the same reaction among party functionaries as did the mention of the devil among believers in the Middle Ages'. Tagebuch, 692.

97 Guntolf Herzberg, 'Emst Bloch in Leipzig: Der operative Vorgang “Wild" ', Zeitschrift für Geschichtswissenschaft, Vol. 42, no. 8 (1994), 686.

98 Loest, Durch die Erde, 293.

99 Ende, $184-5$.

$100 \quad$ Ibid., I 86, I89-9o; Loest, Durch die Erde, 292. 
refused and was arrested. ${ }^{101}$ Loest was likewise arrested, but Zwerenz managed to escape in time to West Berlin.

In June I957 a group of Slavicists from the university in Halle were arrested, and in September their 'leader', Ralf Schroeder, was seized. Like Harich, Schroeder proved willing to reveal every detail of the conspiracy known to him. ${ }^{102}$ People who had been closest to the arrested refused to help their families financially. ${ }^{103}$ Most remained in prison well into the I96os.

After this point, the Ulbricht regime carried its offensive into the ranks of intellectuals who had never entertained the idea of political opposition, namely the social scientists. At risk were the few who had departed furthest from Stalinist dogmas in scholarship, and in some cases felt enthusiasm over events in Poland. ${ }^{104}$ Even more than in the case of the 'Harich-Janka group', any conspiratorial character to these intellectuals' designs was a fabrication of the SED leadership, and in all but a few instances slight prodding was all that was needed to produce massive self-criticism.

Prominent among Ulbricht's targets were historians. In general their response to the Twentieth Party Congress had been restrained; ${ }^{105}$ nevertheless, the editorial board of their major journal, Zeitschrift für Geschichtswissenschaft, was reconstituted and used to discipline the GDR's foremost economic historian, Jürgen Kuczynski. Kuczynski later noted that all the leading East German historians (except Walter Markov) formed a 'united front' against him. ${ }^{106}$ The attack was led by historian Fritz Köhler, not coincidentally a man who had seemed moved by the revelations of Khrushchev. ${ }^{107}$ In the conjuncture of 1957 , perhaps feeling obliged to overcompensate for his past, ${ }^{108}$ Köhler delivered to the Central Committee a series of damaging indictments on Kuczynski, claiming that he had been the true inspiration of revisionism in the GDR, and concocting a conspiracy between Kuczynski, the economist Fritz Behrens and the historian Joachim Streisand. Supposedly Streisand had close contacts with West Berlin. ${ }^{109}$

Despite some reservations as to Köhler's motives, the SED leadership used him to keep Kuczynski fending off pseudo-academic attacks - for example that he had denied the complicity of right-wing Social Democrats in Germany's entry to the First World War - for years. ${ }^{110}$ Such a strategy was not limited to the historical

101 Ibid., 306; Peter Zudeick, Der Hintem des Teufels. Emst Bloch - Leben und Werk (Moos/BadenBaden: Elster, I 985), 237-8.

102 Loest, Durch die Erde, $320-\mathrm{I}$. Schroeder is 'Lehmann'.

103 Ibid., p. 309.

104 See, for example, the report of Jürgen Kuczynski's trip to Poland in April 1956. SAPMO-BA, ZPA IV2/9.04/I $47 /$ I $_{4}$.

105 Fritz Klein, 'Dokumente aus den Anfangsjahren der ZfG', Zeitschrift für Geschichtswissenschaft, Vol. 42, no. I (1994), 43, 54 .

106 Jürgen Kuczynski, Frost nach dem Tauwetter. Mein Historikerstreit (Berlin: Elephanten Press, I993), 64 .

107 SAPMO-BA, ZPA IV2/9.04/1 48

108 Interview with Fritz Klein, Io Sept. I 996.

109 Aktennotiz of 18 March 1957, SAPMO-BA IV2/90.4/148.

110 Jürgen Kuczynski, 'Ein linientreuer Dissident', Memoiren 1945-1989 (Berlin: Aufbau, 1992), 10429. For a discussion of revisionist ideas in the social sciences, see Jänicke, Der dritte Weg, 104-54. 
community: simultaneously less gifted philosophers were mobilised against Ernst Bloch (Rugard Otto Gropp), and less gifted economists (Herbert Prauss) against Fritz Behrens and Arne Benary. As Kuczynski has lamented:

Real Marxists like Fritz Behrens, Walter Markov and myself, real progressive scholars like Hans Mayer and Ernst Bloch, were forced to debate with primitive scholarly figures that were promoted and encouraged by the Party. And the Party supported them, indeed directed them against us, especially in the person of Kurt Hager . . .111

In early 1957, a younger colleague at the Institute for Economics in Berlin supplied the SED Central Committee with detailed reports of conversations with Behrens and Benary, in which the former praised the Leninist period of Soviet history as a time when 'everyone could freely speak their opinion'. Soon these revisionists were forced to recognise a higher principle: in February Benary confessed that 'it has always been clear to me that the power of the working class stands and falls with the unity of the Party. Yet the discussions we had undoubtedly did nothing to promote the unity (Einheit und Geschlossenheit) of the Party, and therefore our political practice did not live up to this correct principle. ${ }^{112}$

After dealing with historians and economists, Ulbricht took the assault to scholars of Marxism-Leninism, who were perhaps his truest allies in academe. ${ }^{113}$ In 1958 , the SED leadership decided to 'annihilate a group hostile to the Party' at Humboldt University's Institute of Social Sciences. One comrade, when told to examine her conscience, confessed to the deepest shame for having procured a copy of Khrushchev's speech from her aunt in the West: 'Today I see clearly that the only foundation is solid unlimited trust in our Party." 114

What is remarkable in the behaviour of even the most daring 'revisionists' is the way in which slight pressure caused them to splinter, and often deny one another in the hope of regaining the Party's favour. Cases of solidarity with the victims are all but unknown, despite the supposed mass support their views enjoyed. Loest recalled the moments before he was expelled from the SED: 'He had known some of the people in the meeting for years. One person with whom he had played cards for years swore never to have been his friend. He encountered anger and disgust, sometimes feigned, sometimes real.'115 When he fell into disfavour in 1953 , Gerhard Zwerenz recalled that 'in the great city of Leipzig hardly a human being attempted to speak to him'. ${ }^{116}$ Writer Wieland Herzfelde dared defend Zwerenz in a meeting in January 1957 , but after a leading functionary called Zwerenz an enemy of the Party, he quickly asked for the podium again and avowed that he had 'not wanted to ally himself with enemies of the Party'. ${ }^{117}$ At the January I956 Congress

111 Kuczynski, Historikerstreit, 76.

112 The conversation took place at Behrens's weekend house. SAPMO-BA ZPA IV2/9.04/402/ I 23-8, I60.

113 Richert, Hochschulpolitik, 136. Even the 'doctrinaire Stalinist' Hanna Wolf was implicated. She subsequently aided Ulbricht in defeating Schirdewan. Jänicke, Der dritte Weg, 124 -

114 Cited in Mitter and Wolle, Untergang, 282.

115 Loest, Durch die Erde, 312.

116 Zwerenz, Der Widerspruch, IоI.

117 Loest, Durch die Erde, 304. 
of the East German Writers' Union, Stefan Heym had dared to contradict Walter Ulbricht to his face. He later recalled the coffee break that followed:

An isolation as deadly as the one in which S.H. and his wife Gertrude found themselves in the whirl of the crowd during this half hour in the foyer of the congress hall is hardly imaginable outside really existing socialism. Only here is people's instinct so well developed for the dangerous glow radiated by a person under an official ban. A single person breaks through the invisible wall, and this not a German, but rather a Turk: Nazim Hikmet. ${ }^{118}$

Perhaps most poignant is the example of Walter Janka. Though they had enlisted his help in 'rescuing' Georg Lukács from Budapest in November 1956, Johannes R. Becher and Anna Seghers refused to come to the aid of the editor who was arrested the following year. He later described the trial:

The writers in attendance, from Anna Seghers and Willi Bredel to Bodo Uhse, did not take part in the screaming. They remained silent. Their faces were pale. . . The face of Heli Weigel, the widow of Brecht, who had shown Janka her sympathy by winking at him, had become ashen. She stared into space, full of consternation. The failure of even one of the friends of Lukács who had come to the trial to protest the untrue allegations was for Janka the worst disappointment during the trial. ${ }^{119}$

Gustav Just likewise wondered at the failure of Janka's associates to speak a word in his defence:

And where were Seghers, Bredel, Uhse and all the others in his time of trouble? I can report something positive about only one of them: Ludwig Renn. Shortly after Janka's arrest he came to me in the editorial office. He was angry, but was able to control himself in his typically reserved way. He asked me how he could send Janka a pack of cigarettes with his best greetings. I advised him to try the state prosecutor's office. As Janka later told me, he received the greetings. What that can mean for a prisoner who feels abandoned by everyone, one can only imagine. ${ }^{120}$

Party and non-Party intellectuals alike had internalised the Leninist interdiction of factions. Jürgen Kuczynski, even decades after the fact, felt proud to have prevented his students from forming a school. In correspondence and discussions with the Party powerful, Ernst Bloch denied the school that had formed around him. ${ }^{121}$ And after Bloch decided to stay in the West in $196 \mathrm{I}$, Kuczynski denounced him in an open

118 Heym, Nachnuf, s98.

119 Janka, Schwierigkeiten, 90-4.

120 Just, Zeuge, $123-4$.

121 In a discussion with Central Committee functionaries on $25 \mathrm{Jan}$. I957, Bloch quickly distanced himself from students Zehm and Kleine, professing he could not be held 'responsible for their thinking'. SAPMO IV2/9.04/163/28. Three days earlier he wrote to the Rector of Karl-Marx-University, G. Mayer, that when: 'the Horthy regime was on the rise in Hungary, I told the head of the institute: "It's high time now. When will the Red Army finally march in?"' He further wrote of his 'deep differences' with the arrested Wolfgang Harich, and emphasised the care he had taken to hire only graduate students who belonged to the SED, 'this in distinct contrast to other institutes at the KarlMarx-University'. Ibid., IV2/9.04/163/15-26. In Dec. 1957, Bloch wrote to the SED leadership: 'If Zwerenz calls himself my student, then this is incorrect'. Ibid., IV2/2/569. For the view that Bloch remained loyal to his students, see Helga Grebing, Der Revisionismus: Von Bemstein bis zum 'Prager Frühling' (Beck: Munich, 1977), i65. 
letter, signing 'hatefully yours' (Verachtungsvoll). ${ }^{122}$ But of course, several years earlier, Bloch had publically denied himself, declaring 'it is the German Democratic Republic on whose ground I stand . . criticism can be objective only if it takes place on the ground of the Republic'. ${ }^{123}$ He was echoing words writen by East Germany's other great critical intellect, Bertolt Brecht. On 17 June 1953, Brecht wrote Ulbricht: 'At this moment, I feel a need to assure you of my solidarity [Verbundenheit] with the Socialist Unity Party of Germany.' He was a 'Marxist who stood loyally on the ground of the workers' and peasants' state'. ${ }^{124}$ Happy indeed a land that does not require heroes.

Explanations for the unusual subservience and atomisation of East German intellectuals can only be preliminary, but the East Central European context does give some hints. In terms of politics that context was nearly uniform: under common ideological pressures from Moscow, East Central Europe's intellectuals became united in their dedication to socialism and anti-fascism. During the Stalinist period, even the anti-Soviet intellectuals of Poland collaborated with the new regime, and leading authorities embraced the new orthodoxies and styles. ${ }^{125}$ What distinguished the intellectuals of various societies were their cultural origins. The Polish intellectuals who formed a 'bloc' against the Party in 1955 derived from a formation called the 'intelligentsia', which itself derived in complex ways from the Polish gentry. ${ }^{126}$ Stubborn legends about their group's ancient and exalted geneology reinforced their loyalty to it. ${ }^{127}$

As has been described above, any East German intelligentsia had been formed by the Party. No revelations about Stalin's crimes could shake that intelligentsia's primary loyalty to its creator. After Stalinism, Polish intellectuals evolved away from the Party as a group, regardless of any attachment to Marxism. When in 1964 the head of the Polish writers' union, the 'servile' writer Jaroslaw Iwaszkiewicz, accepted the Polish Party's decision to toughen censorship, thirty-four prominent intellectuals drafted a letter of protest to the Party leadership. Among the signatories were Catholics such as Stefan Kisielewski and Jerzy Turowicz as well as lapsed or lapsing Communists such as Jan Kott or Jerzy Andrzejewski. A number of prominent young writers still in the Party, for example Tadeusz Konwicki or Kazimierz Brandys, refused to condemn the letter. ${ }^{128}$ All these intellectuals implicitly claimed to play the traditional role of their nation's conscience.

122

123

124

Vol. 2 (Berlin/Weimar: Aufbau, 1988), 493-4; Alfred Kantorowicz, Etwas ist ausgeblieben: zur geistigen Einheit der deutschen Literatur nach 1945 (Hamburg: Christians Verlag, I985), I 47, 2 I 4-I 5.

125 See in this regard esp. the interview with Zbigniew Herbert, in Trznadel, Hanba, and Leopold Tymmand, Dziennik 1954 (Warsaw: Res Publica, 1989).

126 Aleksander Gella, Development of Class Stnucture in Eastem Europe: Poland and her Southem Neighbors (Albany, NY: State University of New York Press, 1989).

127 For the famous critique, see Józef Chalasinski, Spoleczna genealogia inteligencji polskiej (Kódz: Czytelnik, r946).

128 Raina, Opposition, 74-82; Friszke, Opozycja, 178-9. 
Such a role could not exist for the few East German intellectuals who challenged Party hegemony, such as Robert Havemann or Wolf Biermann, for the SED had created an intelligentsia in a negative as well as a positive sense. If people did not like SED rule, until I96I they could leave. For Left-leaning intellectuals this step proved very difficult, because within the extremely polarised German political context the SED laid almost exclusive claim to anti-fascism. ${ }^{129}$

In fact, the SED hoped that discontented intellectuals would leave. In I949, Anton Ackermann spoke to leading functionaries about the 'serious problem' of 'emigration of intellectuals', but admitted to distinctions: 'When a reactionary philosopher or historian leaves the Eastern Zone, this only makes us happy. But it's different with physicians, mathematicians, physicists, biologists or technicians, whom we need and cannot replace.' ${ }^{\text {130 }}$

The border thus served a double function: harmful when skilled labour escaped, but beneficial when it permitted the draining away of potential resistance. The SED was the only Communist Party in the Soviet Bloc which could dispose of 'bourgeois' intellectuals in this way; the other parties had to make some sort of compromise.

The open border also made the East German intelligentsia the sole intelligentsia in Europe which had chosen socialism in full consciousness of the realities of East and West. French intellectuals were Stalinists ignorant of Stalinism; Russian or Romanian intellectuals were Stalinists ignorant of the West. This made East German intellectuals' adherence to socialism frequently fanatical. Looking upon the 'restorationist Adenauer regime' of the I950s, they were convinced that they chose either socialism or fascism. Perhaps the best-known East German dissident, the chemist Robert Havemann, had been deeply affected by the Twentieth Party Congress. But that changed nothing in his perceptions of the evils of the West, and the need to use Stalinist methods to enforce the Party's understanding of what was right. In June 1957 , he attended an election meeting at which a student alleged that the GDR was not democratic enough. In response Havemann

said that in comparison with West Germany we have practically ideal democratic conditions. He explained this thoroughly and well. It came down to the difference between a prison cell and a good life in which one occasionally gets angry about the refrigerator that keeps going on the blink. Then comrade Havemann got very sharp and said that students who had not understood this after all these years should go work in a factory so that they would understand it. ${ }^{131}$

Antonia Grunenberg, Antifaschismus - ein deutscher Mythas (Reinbek: Rowohlt, 1993), esp. I $13-19$.

130 'Stenographische Niederschrift des Referats des Genossen Anton Ackermann auf der Arbeirstagung über die Frage der Auswahl und Zulassung zum Hochschulstudium', 6 May I949. SAPMO-BA ZPA IV2/9.04/464 (unnumbered). Dietrich Staritz argues that the regime welcomed the flight of many farmers in the early 1950 , as they left behind land used to form agricultural collectives. Geschichte der DDR 1949-1985 (Frankfurt am Main: Suhrkamp, 1985), 92.

131 'Notiz über das Auftreten des Gen. Havemann am I8. Juni 1957 in der Wahlversammlung bei Prof. Neunhöffer', SAPMO-BA, ZPA IV2/9.04/164/105. 
Erich Loest wrote many years later of his difficulty in deciding to escape from East Germany, even under imminent threat of arrest. He remained:

He did not know an alternative. It would have been unthinkable for him to go to West Germany. For him that was Adenauer's capitalist, revanchist state; that was where former Nazi teachers had gone and were receiving fat pension cheques, that was where the Blutrichter of Freisler still meted out justice ... to him, even the most tedious[strapaziös] socialism seemed far more moral and to have a much greater future than the most perfect economic miracle. ${ }^{132}$

Gerhard Zwerenz battled with himself throughout the summer of 1957 over whether to escape arrest by fleeing to West Berlin. He grew darkly sun-tanned during weeks spent camping at public lakes in East Berlin. Despite the risk of prison, Zwerenz returned to Leipzig, where only the coaxing of Karola Bloch could convince him at last to slip away to West Berlin. The case of Bloch's student Günter Zehm is perhaps more impressive. During the summers Zehm had travelled throughout the West, attending the seminars of Merleau-Ponty in Paris, discussing existentialism in West Germany and touring Italy. Upon his return to Leipzig he found the dialectical materialism there 'poor and antiquated'. Yet this only intensified his drive to reform socialism in East Germany. When arrested in 1957 by the Stasi

I looked upon the cops, who pressed me into the car and sat to my right and left holding a pillow over my hands so that no one from the street could see the hand-cuffs, in a certain sense as allies. In the weeks [leading up to the arrest] I had been expelled from the Party, had been forced to leave the university, denied all possibilities of a bourgeois existence, so that I had to work as a peon for a writer. All this injustice had not sufficiently opened my eyes. Only in prison would Communism literally be beaten out of me. I wanted to debate with the interrogating commissars, and they answered with their fists. What a lesson I learned! . . . How my eyes now were opened to the real quality of the German Democratic Republic. How much did I learn in the following years, when murderers and executioners, whom the regime had hired as guards, spied on me, when I was watched over by threatening machine guns and ferocious dogs, and had nothing to read throughout my captivity except Neues Deutschland, the central organ of the SED! $!^{133}$

Zehm later became an editor for the conservative daily Die Welt. Yet for most of Ulbricht's leading victims, years of prison had not been enough to shake their allegiance to the Party: Harich, Schroeder, Janka, Just, Merker, Dahlem, Schirdewan and Herrnstadt all refused to criticise the SED during its reign. They feared upsetting 'Party unity'. Such Leninist loyalty drew sustenance from German political culture's 'conventional unpolitical attitude'. ${ }^{134}$

The open border had helped concentrate the leftist and apolitical traditions of German political culture in one small part. A grotesque example of this combination was related to Gustav Just by the writer Kurt Bartel (who liked to be called ' $\mathrm{KuBa}$ '):

I remembered that $\mathrm{KuBa}$, full of enthusiasm, once told me about comrades who had returned from the Soviet Union and spent fifteen years or more in jails and camps though they had

134 Meuschel, Legitimation, is-22. See also Joppke, Dissidents, 206-12. 
done nothing. Their first path had been to the Central Committee: 'Comrades, I'm back! What would you like me to do now?' Perhaps there is something exalted in such behaviour, but I do not understand this mentality. For me, these are inhabitants of a different planet. ${ }^{135}$

Just may not have 'understood this mentality', but he shared it. He waited until I 989 before releasing memoirs written in the I 960 s that seemed critical of 'socialism' - and the Party.

\section{Conclusion}

The year I956 was a year of heated debate and quiet hope in the German Democratic Republic. Perhaps more than any other year in that country's history, it was a year of the intellectuals. They embodied widely held aspirations for change. Yet the intellectual ferment of 1956 achieved nothing concrete, and even failed to leave traces in the East German collective memory.

The most important factor in accounting for this outcome was the Ulbricht regime. Through a mixture of incentives and terror it kept intellectual opposition divided; and it pursued this policy consistently from the early post-war days. The SED leadership also methodically created its own intelligentsia from I946 onwards, and had achieved impressive results by the early I950s. East German students were more often drawn from the lower classes, and were more often beneficiaries of state aid, than counterparts elsewhere in the region. During periods of political instability they tended to side with the regime. To return to the analysis of William E. Griffith, one might say that the SED resolved the tension between the apparat and intelligentsia by making the two one.

The East German leadership also formed an intelligentsia in the negative sense, and here it had special advantages: the open border permitted discontented 'bourgeois' elements to emigrate freely for over fifteen years. The GDR was the only country in Europe where Communists chose the East in full knowledge of both East and West. The precise function of the open border is one of the most pressing questions in the historical sociology of the GDR, but preliminary research does suggest that people who were more highly educated were over-represented among those 'fleeing the Republic'. ${ }^{136}$ Even after the building of the Wall the regime continued to force dissent westward, and policed entrance to universities almost as carefully as to the Party itself. Dissident challenges of later decades came from outside the Party, from people who had been denied higher education and socially marginalised. ${ }^{137}$

The Soviet Military Administration was central to this double-edged strategy of intelligentsia creation. It could requisition buildings and other supplies necessary to

In I96I 3.4 per cent of the male population of West Germany was university-educated. Of the male refugees from East Germany, the percentage was 7.2. Helge Heidemeyer, Flucht und Zuwandenung aus der SBZ/DDR 1945/1949-1961 (Düsseldorf: Droste, 1994), so.

137 J. Fuchs, R. Jahn, K. Weiss, U. Poppe and G. Jeschonnek all had their path to higher education blocked; the careers of W. Templin and G. Poppe in the Academy of Sciences were terminated. See the biographies in Torpey, Intellectuals, 217-32. 
running the early worker preparation courses (Vorstudienanstalten), and through its security arm helped eliminate opposition to the SED, arresting between 1946 and I 949 the leaders of the Berlin, Leipzig and Rostock student bodies. Nowhere else in East Central Europe did the Soviets become so directly involved in policies of élite formation.

The dynamic of the split nation had not forced these aggressive policies of intelligentsia formation upon the SED. As with other parties in the region, the SED faced alternatives in building a socialist society; it chose to realise the potentials of education for building socialism. Precisely why the Party's leaders, and in particular Walter Ulbricht, valued education and so acutely sensed the dangers of intellectual dissent, remain subjects for further study.

Finally, the East German regime inherited the legacies of an apolitical intellectual community, which felt primary loyalty to the state and Party. No doubt the 'myth of anti-fascism' helped cement these intellectuals' devotion to Party unity, but the East Central European context reveals this factor as by no means decisive. Unlike counterparts elsewhere in the region, the East German intelligentsia had no existence separate from the Party.

\section{Biographical Appendix}

Jerzy Andrzejewski (1909-83)

Polish novelist. Before World War II known as Roman Catholic writer of moralistic drama. Nazi occupation in Warsaw. Drifted leftwards after war, joining PZPR and propagating socialist realism. Broke with Party in 1957 and became founding member of KOR in 1976. Character 'alpha' in Czeslaw Milosz's Captive Mind.

Kurt Bartel (1914-67)

German writer known by pseudonym KuBa. Apprenticeship as interior decorator. Joined SPD in 1933, emigrated to Prague and England. Returned to Germany, joined SED; 1946, co-founder of FDJ (Free German Youth). 1952-4 First Secretary of East German Writers' Union; 1954-67 member of SED Central Committee. From 1956 head dramaturge at People's Theatre in Rostock. Target of Brecht's famous poem 'The Solution'.

Johannes R. Becher (1891-1958)

German poet. Freelance writer; I9I4-I8 morphium addict; 1919 KPD, but 1920-2 strong religious leanings; 1923 rejoined KPD. Experimental and expressionist poetry. 1928 co-founder of Union of Proletarian Writers. From 1935 emigrated to USSR, main editor of journal Intemational Literature. From 1946 member of SED Central Committee. 1953- 6 Minister of Culture; unsuccessful mediation for more liberal cultural policy.

Fritz Behrens (1909-80)

German economist. Apprenticeship as mechanical engineer. 1926 SPD, 1932 KPD. I93 I-S studied economics and statistics in Leipzig. 1935 doctorate on finance capital. 1939-4I statistician with headquarters of Wehrmacht. 194 I- 5 taught at German University in Prague. 1946 professor in Leipzig; founder of social sciences faculty. 1947 supported 'limitations on academic freedom' and 'monopoly in science' for SED. 1954 co-founder of Institute of Economic Sciences of GDR Academy of Sciences. I95s director of GDR statistics bureau. 1956 with economist Arne Benary supported introduction of worker self-management, flexible price system, decentralisation. After 
massive accusations of 'revisionism' in 1957 writings suppressed; head of department at Institute of Economic Sciences of German Academy of Sciences.

\section{Wolf Biermann (b. 1936)}

German songwriter. Born in Hamburg in Communist working-class family. Jewish father died in Auschwitz. 1953 settled in GDR. Studied political economy. I957-9 apprenticeship at Brecht's Berliner Ensemble. 1963 refused SED membership; friendship with Robert Havemann. 1964 appearances in cabaret 'Distel'. $196 \mathrm{~S}$ forbidden to appear in public; thereafter recordings released in West Germany only. After concert in Cologne in 1976 refused re-entry into East Germany.

Ernst Bloch (1885-1977)

German philosopher. Before World War I studied in Munich, Würzburg; friendship with Georg Lukács. 1917-19 in Switzerland as opponent of war. 1926-33 Berlin; close to Adorno, Benjamin, Brecht, Weill, Kracauer. KPD member. 1933-8 Switzerland, Austria, Czechoslovakia, France. 1938-49 USA. 1949 professor of philosophy in Leipzig; 1949-57 director of Institute of Philosophy in Leipzig; lectures on history of philosophy. 1957 forbidden to teach. August $196 \mathrm{I}$ decided to stay in West Germany, where vacationing when Berlin Wall built. Thereafter professor in Tübingen, supporter of student movement.

\section{Kazimierz Brandys (b. 1916)}

Polish novelist. Studied law at Warsaw University, where he belonged to leftist organisations. After war wrote for leftist weekly Kuźnica and after 1949 propagated socialist realism. Propagated de-Stalinisation with similar vigour. Thereafter drift to theatre of the absurd and in the 1970 s the dissident movement.

Willi Bredel (1901-64)

German writer. Apprenticeship as tumer, 1919 KPD. Work as journalist and turner. 1934 flight to Soviet Union; 1937/8 Spanish Civil War as commissar. From 194I military service for Soviet Union. Returned in 1945 as member of KPD initiative group for Mecklenburg. I950 co-founder of East German Academy of Arts. 1953-6 chief editor of Neue Deutsche Literatur. 1954-64 Member of SED Central Committee.

\section{Hermann Budzislawski (190I-78)}

German journalist. I9I9-2 I studied economics and poltical science in Tübingen. Dissertation, The economics of human hereditary factors. Freelance journalist; work for Weltbühne. 1929 SPD. After 1933 emigrated to Prague, Paris and USA; worked for emigré newspapers. 1948 returned to Germany and joined SED. $1948-66$ professor for intemational press in Leipzig.

\section{Eduard Claudius (19I I -76 )}

German writer. Apprenticeship as bricklayer. 1932 KPD. After 1934 emigrated to Switzerland, 1936-8 Spanish Civil War. 1945-8 Western zones; work in Bavarian Ministry for De-Nazification. 1948 Potsdam, worked as writer. 1956 First Secretary of East German Writers' Union. 19569 GDR consul in Syria; 1959-6I ambassador to North Vietnam.

Hans Freyer (1887-1969)

German philosopher, sociologist. Studied theology, philosophy economics; 19I I PhD. I922 professor of philosophy in Kiel. 1925 first professor of sociology in Germany at Leipzig. 1938-44 visiting professor and Director of German Cultural Institute in Budapest. After war refused teaching post in Leipzig because of earlier writings supportive of National Socialism. I 948 worked in Wiesbaden with Brockhaus publishers; 1953-55 professor in Münster. Important and controversial voice of German conservatism. 
Otto Grotewohl (1 894-1964)

German politician. Apprenticeship as printer. 1912 SPD. 1914-I8 soldier. I9I8 USPD. 1920-6 member of Landtag in Braunschweig. 1922 SPD. 1923 Minister of Justice; 1926-30 auditor at the Higher School for Politics at Berlin University. 1925-33 Deputy of Reichstag. 1933-45 businessman in Hamburg and Berlin. I945 co-chair of SPD in Berlin; presided over Party in Soviet Zone during forced unification with KPD in April 1946. 1946-54 co-chair of SED; 194964 Politbureau of SED.

\section{Kurt Hager (b. 1912)}

Chief SED ideologue. 1930 KPD. 193 I Abitur. 1933-45 emigrated to France, Spain, England. 1945 director of department for Party schooling; 1949 professor of philosophy Humboldt University. From I954 Central Committee of SED. From 1952 head of department for science and higher education in SED Party executive. I95s Secretary for Science and Culture in Central Committee. From 1963 member of SED Politbureau. 1990 expelled from SED-PDS.

\section{Wolfgang Harich (I923-95)}

German philosopher. 1942-44 Wehrmacht (deserted). I945 KPD. I945-50 intensive work as journalist. 1946-5I studied literature and philosophy in Berlin. I950-4 part-time editor at Aufbau publishing house. I95 I-4 docent for philosophy in Berlin. 1953-6 chief editor Deutsche Zeitschrift fur Philosophie. 1956-64 prison for 'formation of conspiratorial group hostile to the state'. From 1975 freelance scholar in East Berlin. 1979 invalid. 1979-81 Austria and West Germany; worked in peace and ecology movement.

\section{Gerhard Harig (1902-66)}

German historian of science. I922-7 studied physics in Leipzig and Vienna. 1928 doctorate at Aachen with work on absorption spectrum of mercury. 1933 KPD, emigrated to Soviet Union, worked at Institute of Physics at Leningrad Technical University. 1938 sent to Germany for antifascist work; arrested and interned in Buchenwald until 1945. 1947 professor of history of science at Leipzig University. 1951 State Secretary for Higher Education. Replaced in 1957 by hardliner Wilhelm Gimus, and returned to teaching.

Robert Havemann (1910-83)

German chemist. 1929-33 studied in Berlin, Munich. Close to KPD. Doctorate 1935. 1943 arrested for activity in anti-fascist opposition group 'European Union'; sentenced to death. Survived in Brandenburg prison by conducting experiments supposedly important for the conduct of war. 1945-50 director of Berlin Institute of Kaiser-Wilhelm Society, 1946 professor in Berlin. 1950-4 assistant rector for student affairs, responsible for repression of politically non-conformist students. Strongly affected by revelations of zoth Party Congress, became most important Marxist critic of East German regime. 1964 lost teaching positions and Party membership. Thereafter under permament surveillance by Stasi. In early i 980 s supported independent peace initiatives in GDR.

Stefan Heym (b. 1913)

German-American author. Studied philosophy and German in Berlin. Emigtated to Czechoslovakia and the USA. Completed studies at the University of Chicago, and began writing fiction in English. 1943-5 US Army; co-founder of Munich-based paper Neue Zeitung. Dismissed from Army for pro-Communist sympathies. I952 emigrated to GDR, where continued writing and gained reputation as thom in the side of the SED, though loyal to 'socialism'. After I 989 elected to Bundestag for successor Party to SED, the Party of Democratic Socialism, though never a member of SED or PDS.

Wieland Herzfelde (1896-1988)

German writer. Soldier in World War I. 1917-33 co-founder of Malik publishers in Berlin with 
brother John Heartfield. I919 KPD. 1933-9 director of Malik publishers in Prague, voice of the revolutionary German Left and Dadaism. 1939-48 in New York as journalist and book dealer. Retumed to Germany as professor of sociology of modern literature at Leipzig University.

Jaroslaw Iwaszkiewicz (I 894-I980)

Polish poet. 1912-18 studied law and music in Kiev. I9I 8 emigrated to Warsaw. Author of popular novels, poetic prose, librettos for Szymanowski. Member of 'Skamander'. Occupation in Warsaw; home outside Warsaw meeting place for intellectuals. After war leading literary figure in Poland; president of Writers' Union.

Walter Janka (1914-94)

German editor. By trade typesetter. 1932 KPD. 1933-5 political prisoner. 1935 deported to Czechoslovakia. 1935/6 secret work in Germany. 1936 battalion commander in Spanish Civil War. 194I-7 exile in Mexico. I947 returned to Germany; personal secretary to Paul Merker. From I952 director of Aufbau publishing house. 1956-60 imprisoned for 'boycott propaganda' (Boycott-Hetze). After release unemployed, then dramaturge at DEFA film studios. Radio presentation of Janka's memoirs in October 1989 a highpoint of the East German revolution.

Gustav Just (b. I92I)

German writer. From Bohemian Communist family. Served in Wehrmacht. Graduate of a 'new teacher' course after war. General Secretary of East German Writers' Union 1954-6; assistant editor of cultural weekly Sonntag. Imprisoned 1957-61. Thereafter translator. Elected to Parliament in Brandenburg 1990 , but forced to resign after revelations of involvement in Wehrmacht commando that executed partisans in Ukraine.

Alfred Kantorowicz (1899-1979)

German literary scholar. Veteran of World War I. Studied law and literary history. 1923 LLD. Worked as Paris cultural correspondent of the Neue Vossische Zeitung. 193 I KPD. 1933 emigrated to France; with R. Rolland, A. Gide, H. G. Wells and H. Mann founded German Library of Freedom. 1936-8 officer in international brigades in Spain. 1941 flight to USA. Director of foreign news bureau CBS. 1946 retumed to Berlin, editor of journal Ost und West (closed I949). I949 professor of German literature at Humboldt University. Research on exile literature; editor of the works of H. Mann. Escaped to West Berlin 1957.

Stefan Kisielewski (I9I I-9I)

Polish composer and publicist. Studied Polish philology at Warsaw University; music studies in Paris 1938-9. During Nazi occupation official in underground state's cultural department. Regular columnist for Tygodnik Powszechny, except 1953-6 and 1968-71. 1957-65 Deputy in Seym. Multiple Polish and foreign awards.

Tadeusz Konwicki (b. 1926)

Polish writer. 1944-5 officer Home Army. Studies Polish philology at Jagiellonian University (Kraków). Member of editorial staff of leftist journals Odrodzenie, Nowa Kultura. From 1954 film director and stage designer. Late 1960 s expelled from PZPR, engagement for university students persecuted by regime.

Jan Kott (b. 1914)

Polish essayist and translator. Studied law and French literature in Warsaw. Began with writings of poetry and French surrealism. Occupation in Lwow and Warsaw, where he joined underground Communist resistance. Editor of leftist Kuźnica after war; doctorate in literature. Professor at Wroclaw. Important tool of Stalinisation of Polish literary establishment but also important voice in the Polish Thaw. Internationally influential interpreter of Shakespeare. 
Jürgen Kuczynski (b. 1904)

German economic historian. Studied philosophy, economics, statistics. 1930 KPD. 1936 emigration to England. 1944-5 statistician with US Army. 1945 President of Central Finance Administration in Soviet Zone. 1946 Professor in Berlin for economic history. 1947-50 President of Society for German-Soviet Friendship. I956 founded the department for economic history in the Institute of History of GDR Academy of Sciences. Author of over I, ooo books.

Erich Loest (b. 1926)

German writer. 1944 Wehrmacht. 1946-50 Leipziger Volkszeitung. I947 SED. From I950 freelance author. I952 novel, The West German Mark Keeps Falling. I952 ABF Leipzig. 1955/6 studied at Johannes R. Becher Institute for Literature in Leipzig. 1957-64 imprisoned for forming counterrevolutionary group. After release published detective stories under pseudonym. From 1980 living in West Germany.

Walter Markov (b. 1909)

German-Slovene historian. I933 KPD. 1934 doctorate on Serbia at the beginning of World War I. I 935 arrested for resistance activities; $1935-45$ inmate of Siegburg prison. I946 SED. Docent at Leipzig University. 1947 habilitation on Balkan diplomacy. 1949-68 Director of Institute of General History in Leipzig. I95 I expelled from SED for 'objectivism' and 'Titoism'.

Hans Mayer (b. 1907)

German literary scholar. 1925-9 studied political science, law, philosophy. Dissertation, The crisis of German political science. Emigrated to France, Switzerland. $1946-7$ in charge of political programming Radio Frankfurt. 1948 professor of literary science in Leipzig. Students in Leipzig include: Christa Wolf, Volker Braun, Uwe Johnson. I963 failed to return from trip to West Germany; became professor in Hanover.

Paul Merker (1 894-1969)

East German politician. Waiter by trade. 1920 KPD. 1923/4 Secretary of KPD in Western Saxony. 1927-45 member of KPD Central Commitee. I940 interned in France; 1942 onwards exile in Mexico. 1946 return to Germany. 1946-50 member of SED Party executive. 1950 expelled from SED for contacts with Noel Field. I950-2 restaurant director. 1952-6 prison. I956 rehabilitated and editor at Volk und Welt publishing house. Said to be rival that Ulbricht feared most.

Ludwig Renn (1889-1979)

German writer. 191 I -20 military officer. Studied Russian, law, history of art. 1928 KPD. 1928-32 Secretary of League of Proletarian Writers. 1933-5 prison. Emigration, then participation in Spanish Civil War and exile in Mexico. 1947 returned to Germany. Professor of anthropology in Dresden. From 1952 freelance writer.

Karl Schirdewan (b. 1907)

East German politician. Transport worker. 1925 KPD. 1934-45 Nazi concentration camps. 1946 in charge of checking behaviour of SED members during Nazi period. Functions in Saxony. 1952 responsible for department 'leading organs of the parties and mass organizations'. 1953-8 Politbureau. 1958 lost all Party functions, 1959 recanted. 1958-65 director of state archival administration of GDR in Potsdam.

Ralf Schröder (b. 1927)

1944 Wehrmacht. 1946 SED. 1946-\$1 studied history and Russian in East Berlin. I95 I-3 taught Russian at Greifswald University; 1953-7 Leipzig University. Doctorate on the young Gorki. 1957 expelled from SED and arrested; $1957-64$ prison. 1966-88 editor in charge of Russian at Volk und Welt publishing house. 
Anna Seghers (1900-1983)

German writer. $1924 \mathrm{PhD}$. 1928 Kleist Prize for first short stories. $1928 \mathrm{KPD}$, member of League of Proletarian Writers. 1933 arrested by Gestapo; emigrated to Switzerland, France, Mexico. 1947 returned to Germany. 1952-78 chair of East German Writers' Union. Remarkable for absolute loyalty to Party line; supported repression of Biermann.

Joachim Streisand (1920-80)

East German historian. Studied in East Berlin. 1948 SED. Dissertation on 'imperialist German sociology'. Co-founder of Zeitschrfit für Geschichtswissenschaft. Responsible for early nineteenthcentury German history. Unlike colleagues, preferred not to work in collective. 1963 professor of history Humboldt University.

Jerzy Turowicz (b. 1912)

Polish journalist and writer. 1939 graduated from Jagiellonian University with degree in philosophy. From I945 editor of Roman Catholic socio-cultural weekly Tygodnik Powszechny. 1953-6 forbidden to continue as editor of Tygodnik Powszechny for refusal to print article on Stalin's death. 1956 reinstated. 1945-82 member of Polish Journalists' Association. Recipient of numerous Polish and foreign awards.

Bodo Uhse (1904-63)

German writer. I927 NSDAP. After 193 I close contact with KPD. 1935 joined KPD. Exile in France, Spain, Mexico. 1948 returned to Germany. 1950-2 chair of East German Writers' Union. I950-4 delegate to East German Parliament.

Paul Wandel (1905-94)

East German politician. Machinist by trade. 1926 KPD; KPD Secretary in Baden. 1933-45 emigrated to USSR, teacher at Comintern school. 1945-9 President of German Education Administration in East Berlin (DVV). 1949- 52 Minister of Education. 1953-57 Secretary for Education and Culture in Central Committee.

Friedrich Wolf (1888-I953)

German writer. I9I3 MD. November 1918 member of Workers' and Soldiers' Council in Dresden. Functionary in USPD. I919 first dramas performed. Worked as physician. 1928 KPD. I933-45 emigrated to Soviet Union. I945 returned to Germany. Co-founder of DEFA studios. Father of Stasi general Markus and filmmaker Konrad.

Ernst Wollweber (1 898-1967)

East German politician. Sailor by trade. 1918 involved in mutiny in Kiel. 1919 KPD; 1921 onwards, member of Central Political Council. 1933 emigrated to Soviet Union, 1936-40 Scandanavia. Arrested in Sweden, but released in 1943 to Soviet Union at its request. 1946 returned to Germany. 1950-3 State Secretary in Ministry of Transport. I953 State Secretary then Minister of State Security (Stasi). I 958 removed from Central Committee with K. Schirdewan for 'factional activity'.

Amold Zweig (1887-1968)

German writer. 1907-I 4 studied German and philosophy. From 1905 wrote fiction. 1914-18 soldier. From I 923 worked for Berlin-based Jüdische Rundschau. Member of Sociery of Friends of the New Russia. I 933 emigrated to Palestine. 1948 retumed to Berlin. 1949-67 member of East German Parliament.

Gerhard Zwerenz (b. 1925)

German writer. 1942 volunteered for Wehrmacht. I944 deserted; $1944-8$ prisoner of war in 
Soviet Union. I948 East German People's Police, SED. 1952-6 studied philosophy in Leipzig. Student of Bloch. I957 expelled from SED and fled to West Berlin to escape arrest.

Sources: Czeslaw Milosz, The History of Polish Literature (Berkeley, CA: University of California Press, 1983); Günther Buch, Namen und Daten: Biographien wichtiger Personen der DDR (Bonn: Dietz, 1973); Jochen Cerny (ed.), Wer war wer - DDR. Ein biographisches Lexikon (Berlin: Ch. Links, I992); John C. Torpey, Intellectuals, Socialism, and Dissent. The East German Opposition and Its Legacy (Minneapolis, MN: University of Minnesota Press, 1995); Juliusz Stroynowski (ed.), Who's Who in the Socialist Countries of Europe (Munich: K.G. Saur, 1989); W. Killy and R. Vierhaus (eds.), Deutsche biographische Enzyklopädie (Munich: K. G. Saur, I989). 